Jurnal Inkofar* Volume 1 No. 2, Desember 2017 * ISSN: 2615-3645 (Print) / 2581-2920 (Online)

Tersedia secara online di: http://www.politeknikmeta.ac.id/meta/ojs/

\title{
APLIKASI SISTEM PAKAR UNTUK MEMPREDIKSI JENIS PENYAKIT YANG DIDERITA OLEH BAYI MENGGUNAKAN METODE CERTAINTY FACTOR
}

\author{
Febie Elfaladonna' $^{1)}$, Dr. Ir. Gunadi Widi Nurcahyo, MSc. ${ }^{2)}$, Dr. Ir. Sumijan, MSc. ${ }^{3)}$ \\ Politeknik META Industri Cikarang \\ Email : febieelfaladona0411@gmail.com \\ Program Pasca Sarjana, Universitas Putra Indonesia "YPTK", Padang \\ Email : gunadiwidi@yahoo.co.id \\ Program Pasca Sarjana, Universitas Putra Indonesia "YPTK", Padang \\ Email : soe@upiyptk.ac.id
}

\begin{abstract}
Advances in technology and computer science covers all aspects of knowledge without exception the health field. One of the very computer science plays an important role in the field of health is an expert system. Expert system can be used to facilitate the work of the experts in decision making. The existence of the service in the form of expert system aims to determine the type of the disease one of the diseases that commonly suffered by babies. The methods used to make the expert system this is a Certainty Factor method is a method to prove a fact that is for sure or not sure. This method is particularly suitable applied to determine something that nature has not yet been confirmed. This expert system application will be created using the programming language PHP and the MySQL Database. Application of expert system created a very effective help parents to predict the types of illnesses suffered by babies.
\end{abstract}

Keywords: Expert System, Diseases Of Infants, Certainty Factor, PHP MYSQL.

ABSTRAK

Kemajuan ilmu teknologi dan komputer meliputi semua aspek pengetahuan tanpa terkecuali dalam bidang kesehatan. Salah satu ilmu komputer yang juga memiliki peran dalam bidang kesehatan adalah sistem pakar. Sistem pakar dapat digunakan untuk memfasilitasi kerja para ahli dalam pengambilan keputusan. Sistem pakar yang digunakan dalam bidang kesehatan adalah untuk menentukan jenis penyakit yang dalam penelitian ini adalah jenis penyakit yang diderita oleh bayi. Metode yang akan digunakan dalam pembuatan sistem pakar adalah metode certainty factor yang merupakan sebuah metode untuk membuktikan fakta tersebut pasti atau tidak. Metode ini sangat cocok diterapkan untuk menentukan sesuatu yang sifatnya belum pasti. Aplikasi sistem pakar ini akan dibuat dengan menggunakan bahasa pemrograman PHP dan database MYSQL. Sistem pakar yang dibuat akan sangat efektif untuk membantu orang tua dalam memprediksi jenis penyakit yang diderita oleh bayi.

Kata Kunci: Sistem Pakar, penyakit bayi, Certainty Factor, PHP MYSQL.

\section{PENDAHULUAN}

Sistem Pakar adalah aplikasi berbasis komputer yang digunakan untuk menyelesaikan masalah sebagaimana yang dipikirkan oleh pakar. Pakar yang dimaksud adalah orang yang mempunyai keahlian khusus yang dapat menyelesaikan masalah yang tidak dapat diselesaikan oleh orang awam. Sebagai contoh, dokter adalah seorang pakar yang mampu mendiagnosis penyakit yang diderita pasien serta dapat memberikan penatalaksanaan terhadap penyakit tersebut (Swono Sibariang, 2015).

Dalam penyusunannya, Sistem Pakar mengkombinasikan kaidah-kaidah penarikan kesimpulan (Inference Rules) dengan basis pengetahuan tertentu yang diberikan oleh satu atau lebih pakar dalam bidang tertentu. Kombinasi dari kedua hal tersebut disimpan dalam komputer, yang selanjutnya digunakan dalam proses pengambilan keputusan untuk penyelesaian masalah tertentu (Mujilahwati, 2014). Penyakit yang diderita bayi sering disebabkan oleh sistem imunitas atau sistem kekebalan tubuh yang belum terbangun secara sempurna. Keadaan ini merupakan kejadian yang paling banyak membuat para orang tua merasa was-was dan tak berdaya ketika sakit mendadak yang menimpa anak mereka terutama pada bayi yang secara harfiah belum bisa menjelaskan tentang keluhan yang dirasakannya. Tidak hanya itu, bahkan gejala yang tampak secara kasat mata saja banyak orang tua 
yang tidak mengetahui jenis penyakit apa yang sedang diderita oleh bayi tersebut. Hal ini akan membuat penanganan medis yang seharusnya diberikan kepada sang bayi menjadi terlambat dan bisa berakibat fatal. Oleh sebab itu diperlukan suatu sistem atau aplikasi yang lebih praktis dan memiliki pengetahuan layaknya seorang pakar agar mampu memberikan pengetahuan bagi para orangtua untuk memprediksi sendiri jenis penyakit yang diderita oleh bayi berdasarkan gejala yang dirasakan.

\section{LANDASAN TEORI}

\subsection{Kecerdasan Buatan (Artificial Intelligence)}

Artificial Intelligence (AI) atau kecerdasan buatan merupakan cabang dari ilmu komputer yang konsern dengan pengautomatisasi tingkah laku cerdas. Pernyataan tersebut juga dapat dijadikan defenisi dari AI.

\subsection{Sistem Pakar (Expert System)}

Sistem Pakar merupakan cabang ilmu dari Artificial Intelligence (AI) yang cukup lama karena keberadaan sistem mulai dikembangkan pada pertengahan 1960. Sistem Pakar yang muncul pertama kali adalah General Purpose-Problem (GPS) yang dikembangkan oleh Newel dan Simon. Sistem Pakar merupakan salah satu bagian dari kecerdasan buatan yang di buat oleh manusia. Sistem ini dirancang untuk dapat menirukan keahlian seorang pakar dalam menjawab pertanyaan dan menyelesaiakan suatu masalah. Dengan bantuan Sistem Pakar seorang yang awam dapat menyelesaikan masalah yang ada sehingga bisa mengambil keputusan yang biasanya dilakukan oleh seorang pakar (Andri Saputra dan Hengki Andrea Taman, 2016).

\subsection{Metode Certainty Factor}

Teori Certainty Factor (CF) mengakomodasi ketidakpastian pemikiran (Inexact Reasoning) seorang pakar. Seorang pakar (misalnya dokter) seringkali menganalisis informasi yang ada dengan ungkapan seperti "mungkin", "kemungkinan besar", "hampir pasti". Untuk mengakomodasi hal ini kita menggunakan Certainty Factor (CF) guna menggambarkan tingkat keyakinan pakar terhadap masalah yang sedang dihadapi (Sutojo, dkk, 2011). Metode 'Net belief' yang diusulkan oleh E.H. Shortliffe dan B.G.Buchanan.

$$
\begin{gathered}
\mathrm{CF}(\text { rule })=\operatorname{MB}(\mathrm{H}, \mathrm{E})-\mathrm{MD}(\mathrm{H}, \mathrm{E}) \\
M B(H, E)\left\{\begin{array}{cc}
1 & P(H)=1 \\
\operatorname{Max}[P(H \mid E), P(H)]-P(H) \\
\operatorname{Max}[1,0]-P(H)
\end{array}\right. \\
M B(H, E)\left\{\begin{array}{c}
1 \\
\operatorname{Min}[P(H \mid E), P(H)]-P(H) \\
\operatorname{Max}[1,0]-P(H)
\end{array}\right.
\end{gathered}
$$

Dimana :

$\mathrm{CF}($ Rule $) \quad$ : Faktor kepastian

MB (H,E) : Measure Of Belief (Ukuran kepercayaan) terhadap hipotesis H, jika diberikan evidence E (antara 0 dan 1).

MD (H.E) : : Measure Of Disbelief (Ukuran ketidakpercayaan) terhadap evidence H, jika diberikan evidence E (antara 0 dan 1).

$\mathrm{P}(\mathrm{H}) \quad$ : Probabilitas kebenaran hipotesis $\mathrm{H}$.

$\mathrm{P}(\mathrm{H} \mid \mathrm{E}) \quad$ : Probabilitas bahwa $\mathrm{H}$ benar karena faktor $\mathrm{E}$.

\subsection{Data Penyakit Yang Sering Diderita Bayi}

1. Cacar Air ( Varicella Simplex)

Cacar air atau biasa yang disebut dengan Varicella Simplex merupakan penyakit yang menyerang kulit. Penyakit ini disebabkan oleh virus Veriola yang akan menyebabkan bintilbintil merah berisi cairan dan dapat ditemukan pada seluruh permukaan tubuh penderita.

2. Kejang (Step/Stuip)

Kejang terjadi akibat adanya kontraksi otot yang berlebihan pada satu waktu tertentu tanpa bisa dikendalikan. Salah satu penyebab terjadinya kejang yaitu demam pada anak. 
Timbulnya kejang yang disertai demam ini di istilahkan dengan kejang demam (Convalsio Febrilis) atau step atau stuip. Umumnya terjadinya kejang ini karena ada kelainan bawaan yang mengganggu fungsi otak bisa juga akibat trauma lahir, adanya infeksi pada saat terakhir lahir, dan proses kelahiran yang susah sehingga sebagian oksigen tidak masuk ke dalam otak bayi.

3. Ruam Popok

Ruam popok adalah peradangan pada kulit bayi yang tertutup popok seperti bokong. Ruam biasanya terjadi karena reaksi kulit terhadap urin dan tinja. Awalnya ditandai dengan munculnya kulit kemerahan pada daerah bokong atau daerah sekitar selangkangan bayi.

4. Diare

Menurut WHO pengertian diare adalah buang air besar dengan konsistensi cair (mencret) sebanyak tiga kali atau lebih dalam satu hari (24 jam). Dua kriteria penting yang harus diingat oleh para orangtua adalah keluarnya feses bayi yang sangat cair dan sering. Penyakit diare merupakan masalah global yang menjadi penyebab kematian pada anak nomor dua setelah pneumonia. Diare sering dikaitkan dengan infeksi gastrointestinal (saluran pencernaan) yang dapat disebabkan oleh berbagai macam organisme seperti bakteri, virus dan parasit.

5. Batuk dan Pilek

Batuk dan pilek dianggap sebagai upaya tubuh untuk mengeluarkan lendir atau benda asing dari saluran pernapasan.

6. Tuberkulosis Pada Bayi

Tuberkulosis pada bayi merupakan infeksi yang disebabkan oleh bakteri Mycobacteriumn Tuberculosis yang menyerang berbagai organ terutama pada paru-paru bayi.

7. Kelelahan Pada Bayi

Merupakan keadaan psikis bayi yang sering tidak terkontrol dimana bayi sering menunjukkan gejala yang sering ditandai dengan rewel atau bayi merengek terus menerus.

\section{ANALISA PROSES}

Pengetahuan ini akan direpresentasikan dalam bentuk Rule yang berguna untuk menghasilkan kesimpulan berupa jenis penyakit yang diderita oleh bayi. Pada dasarnya Rule terdiri dari dua bagian pokok, yaitu bagian Premise atau kondisi dan bagian Conclution atau kesimpulan. Struktur Rule secara logika menghubungkan satu atau lebih kondisi (Premise) pada bagian IF (yang akan menguji kebenaran dari serangkaian data) dengan satu atau lebih kesimpulan (Conclution) yang terdapat pada bagian THEN. Rule merupakan sebuah teknik representasi pengetahuan dengan aturan

\section{IF E Then $\mathrm{H}$.}

Tabel 1. Perbandingan Hasil Metode CF

\begin{tabular}{|c|l|c|}
\hline $\begin{array}{c}\text { Kode } \\
\text { Penyakit }\end{array}$ & Nama Penyakit & $\begin{array}{c}\text { Hasil } \\
\text { Kombinasi CF }\end{array}$ \\
\hline P001 & $\begin{array}{l}\text { Cacar Air (Varicella } \\
\text { Simplex) }\end{array}$ & $28.62 \%$ \\
\hline P002 & $\begin{array}{l}\text { Kejang Demam/ Step/ } \\
\text { Stuip }\end{array}$ & $31.31 \%$ \\
\hline P003 & Ruam Popok & $30.38 \%$ \\
\hline P004 & Diare & $27.84 \%$ \\
\hline P005 & Batuk dan Pilek & $30.30 \%$ \\
\hline P006 & Tuberkulosis Bayi & $30.01 \%$ \\
\hline P007 & Kelelahan & $43.78 \%$ \\
\hline
\end{tabular}


Jurnal Inkofar* Volume 1 No. 2, Desember 2017 * ISSN: 2615-3645 (Print) / 2581-2920 (Online)

Tersedia secara online di: http://www.politeknikmeta.ac.id/meta/ojs/

\section{HASIL DAN PEMBAHASAN}

Berikut merupakan tampilan dari sistem pakar dileksia.

4.1 Halaman Beranda

Halaman beranda merupakan halaman awal Sistem Pakar yang berisi tentang informasi seputar jenis penyakit bayi.

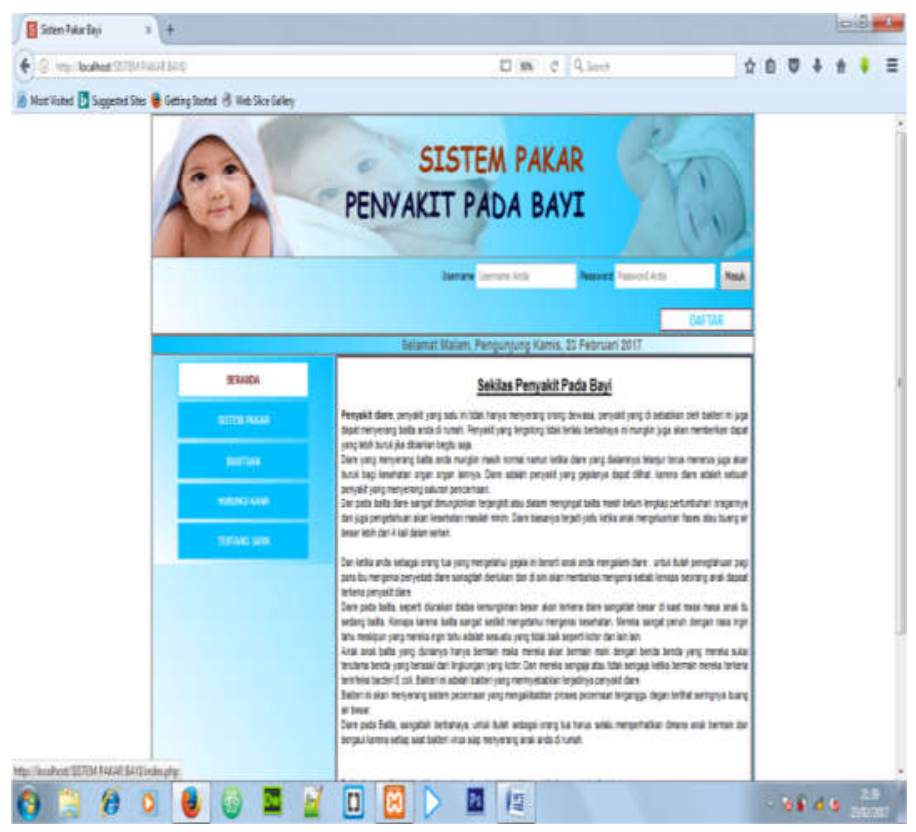

Gambar 1. Halaman Beranda

4.2 Halaman Konsultasi User

Merupakan halaman untuk User melakukan konsultasi. Terdapat lima kriteria yang harus diberikan oleh User ketika melakukan konsultasi : Tidak tahu, Mungkin, Kemungkinan Besar, Hampir pasti, dan Pasti.

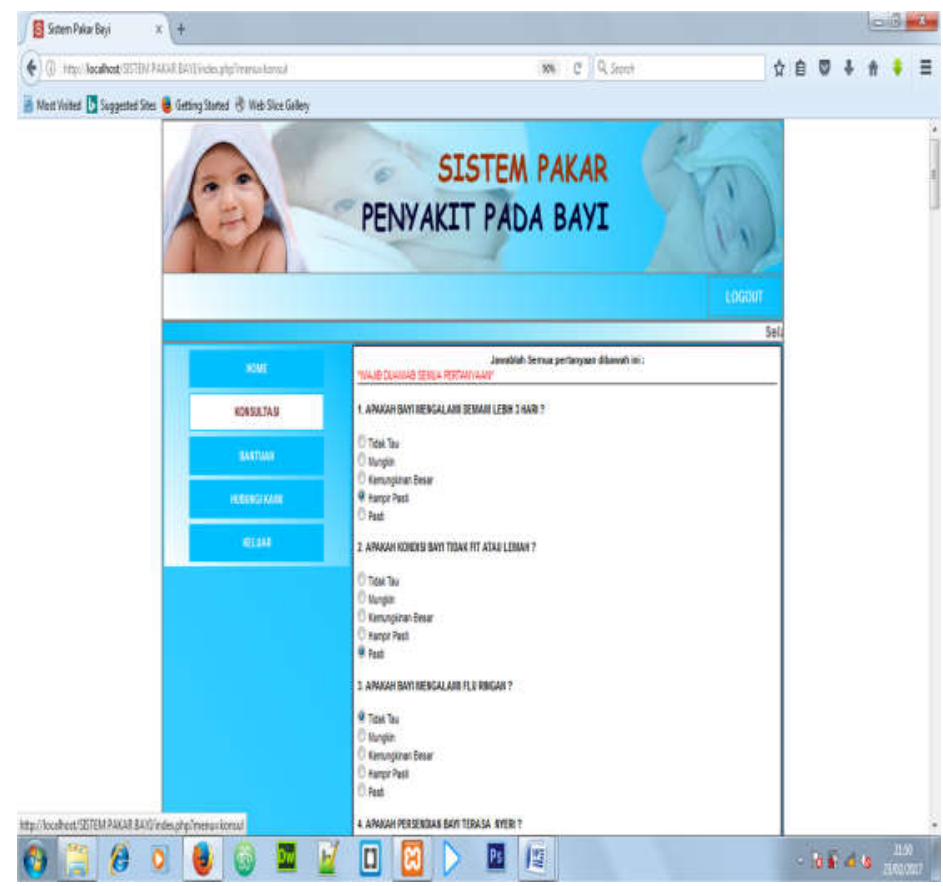

Gambar 2. Halaman Konsultasi User 
Jurnal Inkofar* Volume 1 No. 2, Desember 2017 * ISSN: 2615-3645 (Print) / 2581-2920 (Online)

Tersedia secara online di: http://www.politeknikmeta.ac.id/meta/ojs/

Berikut ini merupakan tabel gejala yang dipilih oleh User beserta nilai kepastian yang diberikan oleh User.

\begin{tabular}{|l|l|c|}
\hline \multicolumn{2}{|c|}{ Gejala yang Anda Pilih } \\
\hline No. & \multicolumn{2}{|c|}{ Gejala } \\
\hline 1. & Bayi mengalami demam lebih dari tiga hari & 1 \\
\hline 2. & Kondisi tubuh bayi tidak fit atau lemah & 1 \\
\hline 3. & Bayi mengalami flu ringan & 1 \\
\hline 4. & Persendian bayi terasa nyeri & 1 \\
\hline 5. & Bayi terlihat rewel & 1 \\
\hline 6. & Dahak bayi tampak benwarna kuning, hijau, atau kecoklatan & 1 \\
\hline 7. & Bayi selalu tampak mengantuk & 1 \\
\hline 8. & Bayi tidak kuat menghisap & 1 \\
\hline 9. & Bayi mengalami gangguan pernafasan & 1 \\
\hline 10. & Terjadi pembesaran hati dan limfa pada bayi & 1 \\
\hline 11. & Bayi merengek terus-menerus & 1 \\
\hline 12. & Tatapan mata bayi kosong & 1 \\
\hline 13. & Mata bayi terlihat sayu & 1 \\
\hline 14. & Bayi memalingkan wajah apabila ada yang mendekat & 1 \\
\hline 15. & Bayi melengkungkan badan ke depan dan ke belakang & 1 \\
\hline 16. & Mengepalkan kedua tangan dan menempelkannya pada pipi & 1 \\
\hline 17. & Tangan dan kaki tampak bergerak mengacak & 1 \\
\hline 18. & Bayi terlihat gelisah & 1 \\
\hline
\end{tabular}

\section{Gambar 3. Gejala Yang Dipilih User}

4.3 Halaman Hasil Konsultasi User

Merupakan halaman untuk menampilkan hasil konsultasi User.

\begin{tabular}{|c|c|c|c|}
\hline \multicolumn{4}{|c|}{ Penggabungan rule } \\
\hline No & Penysiti & Penggabungan & hasil \\
\hline 1 & Cacar Air (Varicella Simplex) & $\begin{array}{l}(0.18+0.18)^{*}(1-0.18)(0.2952+0.08)^{*}(1-0.2952)(0.26444098+0.14)^{*} \\
(1-0.28444098)(0.29749020427428+0.11)^{*}(1-0.29749020427428)\end{array}$ & 0.28628586016496 \\
\hline 2 & Kejang Demam/ Step/ Stuip & $\begin{array}{l}(0.18+0.18) *(1-0.18) \\
(0.2952+0.16) \cdot(1-0.2952) \\
(0.32082496+0.11)^{*}(1-0.32082498) \\
(0.292605559441+0.15)^{*}(1-0.292805559441)\end{array}$ & 0.31309871210907 \\
\hline 3 & Ruam Popok & $\begin{array}{l}(0.15+0.12) \cdot(1-0.15) \\
(0.2295+0.11) \cdot(1-0.2295)(0.26158475+0.15) *(1-0.28158475)\end{array}$ & 0.30392045608744 \\
\hline 4 & Diare & $\begin{array}{l}(0.18+0.16) *(1-0.18) \\
(0.2788+0.13) *(1-0.2788)(0.29482656+0.1) *(1-0.29482856)\end{array}$ & 0.27842120351857 \\
\hline 5 & Batuk Dan Pilek & $\begin{array}{l}(0.17+0.18) *(1-0.17) \\
(0.2739+0.15)^{*}(1-0.2739)(0.30779379+0.13) *(1-0.30779379)\end{array}$ & 0.30304358013744 \\
\hline 6 & Tuberkulosis Вayi & $\begin{array}{l}(0.15+0.13) *(1-0.15) \\
(0.238+0.12) \cdot(1-0.238)(0.272796+0.14) *(1-0.272796)\end{array}$ & 0.300186902384 \\
\hline 7 & Kelelahan & $\begin{array}{l}(0.54+0.45) *(1-0.54) \\
(0.4554+0.42) *(1-0.4554)(0.47674284+0.36) *(1-0.47674284)\end{array}$ & 0.43783168210873 \\
\hline
\end{tabular}

\section{KESMPULAN}

Dari perhtungan diatas, maka didapatkan Kelelahan, dengan Hipotesis 0.43783168210873 atau $43,78 \%$

Untuk penanganan, lakukan langkah-langkah berkut ini:

1. Menghentixan actifitas bermain dengan bayi

2. Peluk bayi dengan lembut dan bisikan kata-łata yang membuat bayi menjadi nyaman.

3. Perika terlebih dahulu apakah bayi lapar atau popoknya basah.

4. Mengajak bayi untuk merasa lebih relax.

5. Apabila bayi tidak ingin tidur maka cobalah untuk menggendongnya atau dengan bantuan ayunan.

\section{Gambar 4. Hasil Perhitungan Rule CF}

Dari hasil perhitungan sistem didapatkan perbandingan yang sama antara hasil perhitungan manual dan perhitungan sistem. 
Jurnal Inkofar * Volume 1 No. 2, Desember 2017 * ISSN: 2615-3645 (Print) / 2581-2920 (Online)

Tersedia secara online di: http://www.politeknikmeta.ac.id/meta/ojs/

\section{PENUTUP}

Berdasarkan perumusan masalah, perancangan, dan penerapan Sistem Pakar untuk memprediksi jenis penyakit bayi maka dapat diambil sebuah kesimpulan, yaitu :

1. Aplikasi yang dibangun dapat memprediksi jenis penyakit yang diderita oleh bayi berdasarkan gejala-gejala yang diinputkan dengan menggunakan metode Certainty Factor untuk menentukan nilai kepastian agar aturan gejala dapat diketahui nilai akhirnya.

2. Metode Certainty Factor diimplementasikan menggunakan Bahasa Pemrograman berbasis Web keputusan berdasarkan nilai kepastian yang telah diinputkan oleh User. Nilai kepastian dipergunakan untuk memprediksi jenis penyakit yang diderita oleh bayi.

\section{DAFTAR PUSTAKA}

Andri Saputra dan Hengki Andrea Taman (2016). "Sistem Pakar Kerusakan Mesin Jahit Dengan Metode Certainty Factor Berbasis Android”. Vol. 1, No. 1, 2016.

Anita Desiani dan Muhammad Arhami (2005). “Konsep Kecerdasan Buatan”. Yogyakarta : ANDI.

Eka Setyarini., Darma Putra., Adi Purnawan (2013). "The Analysis Of Comparison Of Expert System Of Diagnosing Dog Disease By Certainty Factor Method And Dempster-Shafer Method". ISSN : 1694-0784, Vol. 10, Issue. 1, No. 2, 2013.

Fitri Wulandari dan Ihsan Yuliandri. (2014). "Diagnosa Gangguan Gizi Menggunakan Metode Certainty Factor". ISSN : 1693-2390, Vol. 11, No. 2, 2014.

Gatot Fitriyanto., Nur Ahmad Azhar., Muhammad Kurniawan (2016). "Mendeteksi Hama Tanaman Buah Mangga Dengan Metode Certainty Factor". ISSN : 2302-3805, 2014.

Irham Cahya Nugraha dan Herlawati. (2016). " Sistem Pakar Tes Minat Dan Bakat Jurusan Kuliah Berbasis Android Pada SMA Islam Teratai Putih Global Bekasi”. ISSN : 2442-2436, Vol. 11, No. 1, 2016.

Mira Orisa., Purnomo Budi Santoso., Onny Setyawati (2014). 'Sistem Pakar Diagnosis Penyakit Kambing Berbasis Web Menggunakan Metode Certainty Factor". Vol. 8, No. 2, 2014.

Nur Anjas Sari. (2013). "Sistem Pakar Mendiagnosa Penyakit Demam Berdarah Menggunakan Metode Certainty Factor". ISSN : 2301-9425, Vol.IV, No.3, 2013.

Olanloye and Dauda Odunayo. (2014). "An Expert System For Diagnosing Faults in Motorcycle", ISSN : 2305-8269 November 2014.

Rahmad Solikin., Jusak., Erwin Sutomo (2014). "Sistem Pakar Diagnosis Penyakit Pada Ayam Petelur Menggunakan MetodeCeratinty Factor". ISSN : 2338-137X, Vol. 3, No. 2, 2014.

T Sutojo (2011). "Kecerdasan Buatan". Yogyakarta : ANDI OFFSET.

Tb. Ai Munandar., Suharman., Sumiati (2012). "The Use Of Certainty Factor With Multiple Rules For Diagnosis Internal Disease". ISSN ; 2319-4847, Vol. 1, Issue. 1, 2012.

Teguh Bharata Adji., Christine Putri Batara R., Adhistya Erna Permanasari (2015). "Expert System For Diagnosis Of Personality Disorder With Certainty Factor Approach".

Tuswanto dan Abdul Fadlil. (2013). "Sistem Pakar Untuk Mendiagnosa Hama Dan Penyakit Tanaman Bawang Merah Menggunakan Certainty Factor". ISSN : 2338-5197, Vol. 1, No. 1, 2013.

Yasaman Sarlati., Simin Naghavi., Shahram Jafari (2014). "Implementation Of Expert System For Lending With Certainty Factor". ISSN : 2319-6734, Vol. 3, Issue. 4, 2014. 